Research article

Open Access

\title{
Stability-Indic ating LC Method for the Determination of Prasugrel Hydrochloride in Pharmaceutical Dosage Form
}

\author{
Vinod K. AhIrrao ${ }^{1}$, Chabutai S. Patil ${ }^{1}$, Saroj B. Bembalkar ${ }^{1}$, \\ Sanjay B. Ubale ${ }^{1}$, Rajendra P. MARATHE ${ }^{2}$, Rajesh. B. NAWALE ${ }^{2}$, \\ Mahadev G. LANDGE ${ }^{3}$, Rajendra. P. PAWAR * 1 \\ ${ }^{1}$ Department of Chemistry, Deogiri College, Aurangabad-431004 (MS), India. \\ ${ }^{2}$ Government college of Pharmacy, Aurangabad-431004 (MS), India. \\ ${ }^{3}$ Department of Chemistry, Vidyanath College, Parli-vaijnath-431515, India. \\ * Corresponding author. E-mail: rppawar@yahoo.com (R. P. Pawar)
}

Sci Pharm. 2012; 80: 379-391

doi:10.3797/scipharm.1201-05

Published: $\quad$ March $20^{\text {th }} 2012$

Accepted: $\quad$ March $20^{\text {th }} 2012$

Received: January $8^{\text {th }} 2012$

This article is available from: http://dx.doi.org/10.3797/scipharm.1201-05

(c) Ahirrao et al.; licensee Österreichische Apotheker-Verlagsgesellschaft m. b. H., Vienna, Austria.

This is an Open Access article distributed under the terms of the Creative Commons Attribution License (http://creativecommons.org/licenses/by/3.0/), which permits unrestricted use, distribution, and reproduction in any medium, provided the original work is properly cited.

\begin{abstract}
A simple, rapid and precise method was developed for the quantitative estimation of prasugrel hydrochloride in pharmaceutical dosage form. A chromatographic separation of prasugrel and its degradants was achieved with Zorbax XDB $\mathrm{C}_{8}, 150 \times 4.6 \mathrm{~mm}, 3.5 \mu \mathrm{m}$ analytical column using aqueous solution of $0.05 \mathrm{M}$ ammonium acetate $\mathrm{pH} 4.5$ with acetic acid-acetonitrile (40:60 v/v). The instrumental settings include flow rate of $1.0 \mathrm{ml} / \mathrm{min}$, column temperature at $30^{\circ} \mathrm{C}$ and detector wavelength of $254 \mathrm{~nm}$ using a photodiode array detector. Theoretical plates for prasugrel were 7023. Tailing factor for prasugrel was 1.11. Prasugrel was exposed to thermal, photolytic, hydrolytic and oxidative stress conditions, and the stressed samples were analyzed by the proposed method. Peak homogeneity data of prasugrel was obtained using photodiode array detector in the stressed sample chromatograms, which demonstrated the specificity of the method for the estimation in presence of degradants. The described method showed excellent linearity over a range of $10-300 \mu \mathrm{g} / \mathrm{ml}$ for prasugrel. The correlation coefficient is 0.999 . The relative standard deviation of peak area for six measurements is always less than $2 \%$. Overall, the proposed method was found to be suitable and accurate for quantitative determination and stability study of prasugrel in pharmaceutical dosage form.
\end{abstract}




\section{Keywords}

Liquid chromatography - Method validation - Pharmaceutical preparation - Prasugrel hydrochloride

\section{Introduction}

Prasugrel (Fig. 1) is chemically (RS)-5-[2-cyclopropyl-1-(2-fluorophenyl)-2-oxoethyl]4,5,6,7-tetrahydrothieno[3,2-c]pyridin-2-yl acetate. Prasugrel is a novel third-generation oral thienopyridine that reduces the tendency of platelets, the blood particles responsible for clotting, from sticking or clumping together. Prasugrel blocks a specific receptor on the platelet surface, P2Y12 adenosine diphosphate (ADP), preventing platelets from clumping, which can result in clogged arteries and may lead to a heart attack. Prasugrel is more effective by preventing ischemic events in patients with acute coronary syndrome undergoing percutaneous coronary intervention, increase in bleeding and improved net clinical outcome [1-8].

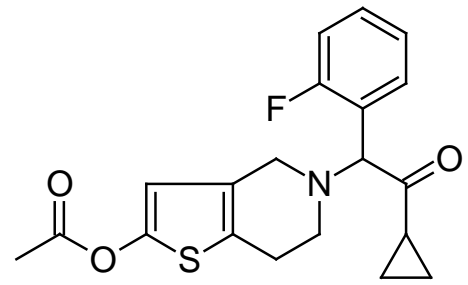

Fig. 1. Chemical structure of Prasugrel

Forced degradation or stress testing is undertaken to demonstrate specificity for developing stability-indicating methods, particularly when little information is available about potential degradation products. The ICH guideline entitled "Stability Testing of New Drug Substances and Products" requires the stress testing to be carried out to elucidate the inherent stability characteristics of the active substances. The aim of stability testing is to prove how the quality of a drug substance or drug product varies with time under the influence of a variety of environmental factors such as temperature, humidity and light. It enables recommendation of storage conditions, retest period and shelf lives to be established. Regulatory agencies recommend the use of stability-indicating methods for the assay analysis of stability samples. Thus, stress studies are required in order to generate the stressed samples, method development and its validation [9]. Forced degradation of prasugrel was performed under stress conditions (acid, alkaline, photolytic, thermal and oxidative). To establish the stability-indicating nature of the method, stressed samples were analyzed by the proposed method. The proposed RP-HPLC method was validated by assessing its specificity, linearity, accuracy, precision, limits of detection and quantification, system suitability parameters, ruggedness and robustness.

Literature survey reveals that three methods are reported for the assay of prasugrel in human serum by using LCMS [10-12]. Previous investigators [13-16] have also reported the assay of prasugrel in pharmaceutical dosage form by using various techniques such as HPLC and spectrometry. But none of the reported HPLC method is stability-indicating. In the present study attempts were made to develop a rapid, economical, precise and accurate HPLC method for the estimation of prasugrel in the presence of its degradants. 


\section{Experimental}

\section{Chemicals and Reagents}

Prasugrel reference standard was provided as a gift sample by Lupin Pharmaceutical Ltd, Mumbai, India. HPLC grade acetonitrile was purchased from Rankem, India. Ammonium acetate, acetic acid and hydrogen peroxide was purchased from Qualigens Fine chemicals, India and sodium hydroxide was purchased from Merck Ltd. India. High pure water was prepared by using Millipore Milli Q plus purification system. 0.45-Pump nylon filter was obtained from Advanced Micro devices Pvt. Ltd. (Ambala Cantt, India). Commercial formulations Prasudoc tablet containing 10mg of prasugrel were purchased from the local market. Other chemicals used were of analytical or HPLC grade.

\section{HPLC instrumentation and Chromatographic Conditions}

The chromatographic system used was Agilent - 1100 series comprised of degasser, quaternary pump, auto injector, column compartment, photodiode array detector and the system was controlled through Chemstation software. Zorbax XDB $C_{8} 150 \times 4.6 \mathrm{~mm}$, $3.5 \mu \mathrm{m}$ (Agilent Technologies, USA) column maintained at $30^{\circ} \mathrm{C}$ using column oven, eluted with mobile phase at the flow rate of $1.0 \mathrm{ml} / \mathrm{min}$. The mobile phase consists of aqueous solution of $0.05 \mathrm{M}$ ammonium acetate $\mathrm{pH} 4.5$ with acetic acid -acetonitrile $(40: 60 \mathrm{~V} / \mathrm{V})$. The mobile phase filtered through $0.45 \mu \mathrm{m}$ nylon filter and degassed in ultrasonic bath prior to use. Measurements were made with injection volume $10 \mu \mathrm{L}$ and ultraviolet (UV) detection at $254 \mathrm{~nm}$. For analysis of forced degradation samples, the photodiode array detector was used in scan mode with a scan range of $200-400 \mathrm{~nm}$. The peak homogeneity was expressed in terms of peak purity and was obtained directly from the spectral analysis report using the aforementioned software.

\section{Standard Preparations}

Standard stock solution $(1 \mathrm{mg} / \mathrm{ml})$ was prepared by dissolving the drug in the diluents, and standard solution was prepared by diluting them to the desired concentration. Diluent used for preparation was composed of water and acetonitrile in the ratio of 70:30 $(\mathrm{v} / \mathrm{V})$.

\section{Preparation of sample Solutions}

20 tablets were taken, and their average weight was calculated. The tablets were crushed to a fine powder; drug equivalent to $50 \mathrm{mg}$ powder was transferred to a $50 \mathrm{ml}$ volumetric flask. To this flask $25 \mathrm{ml}$ of diluent was added and the solution was sonicated for $10 \mathrm{~min}$. with intermittent shaking. The volume is makeup with diluent and centrifuged at 10,000 rpm for $10 \mathrm{~min}$. The centrifuged solution was filtered through $0.45 \mu$ filter. From the filtered solution, $5 \mathrm{ml}$ of solution was transferred into a $25 \mathrm{ml}$ volumetric flask and diluted to requisite volume with diluent.

\section{Procedure for forced degradation study}

Forced degradation of the drug product was carried out under thermolytic, photolytic, acid, base hydrolytic and oxidative stress conditions. 


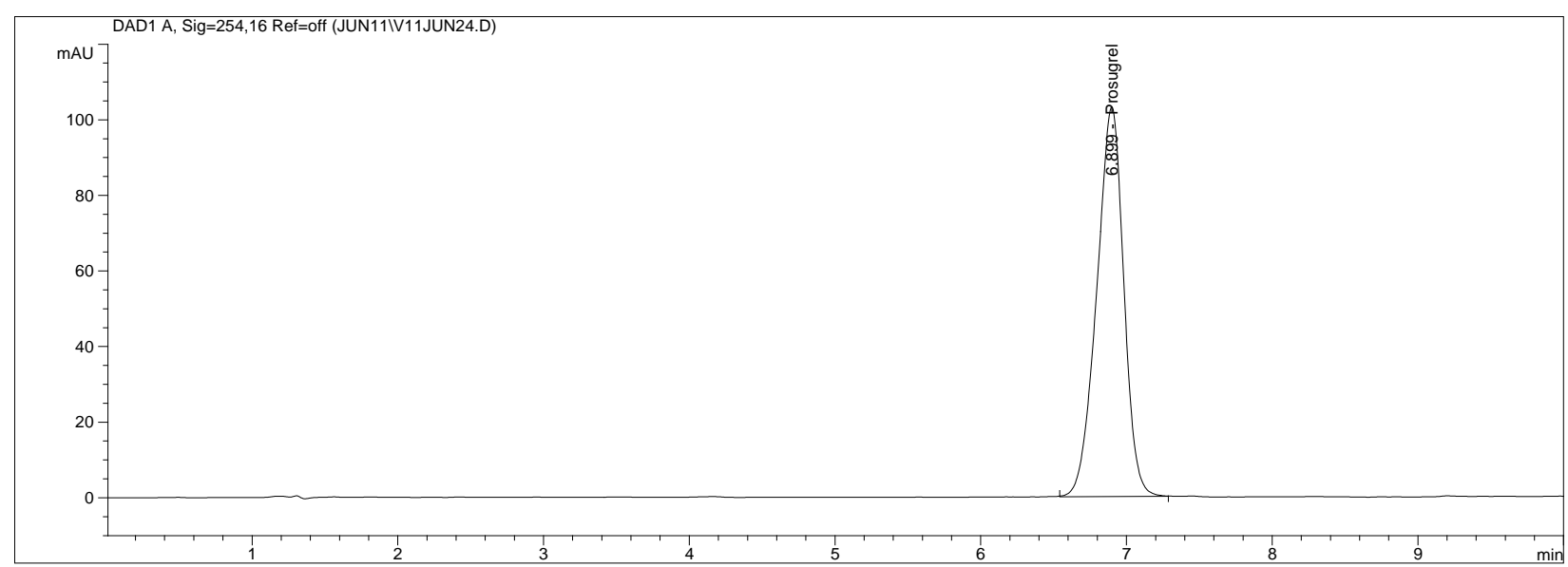

Fig. 2a. Chromatogram of Prasugrel tablet solution.

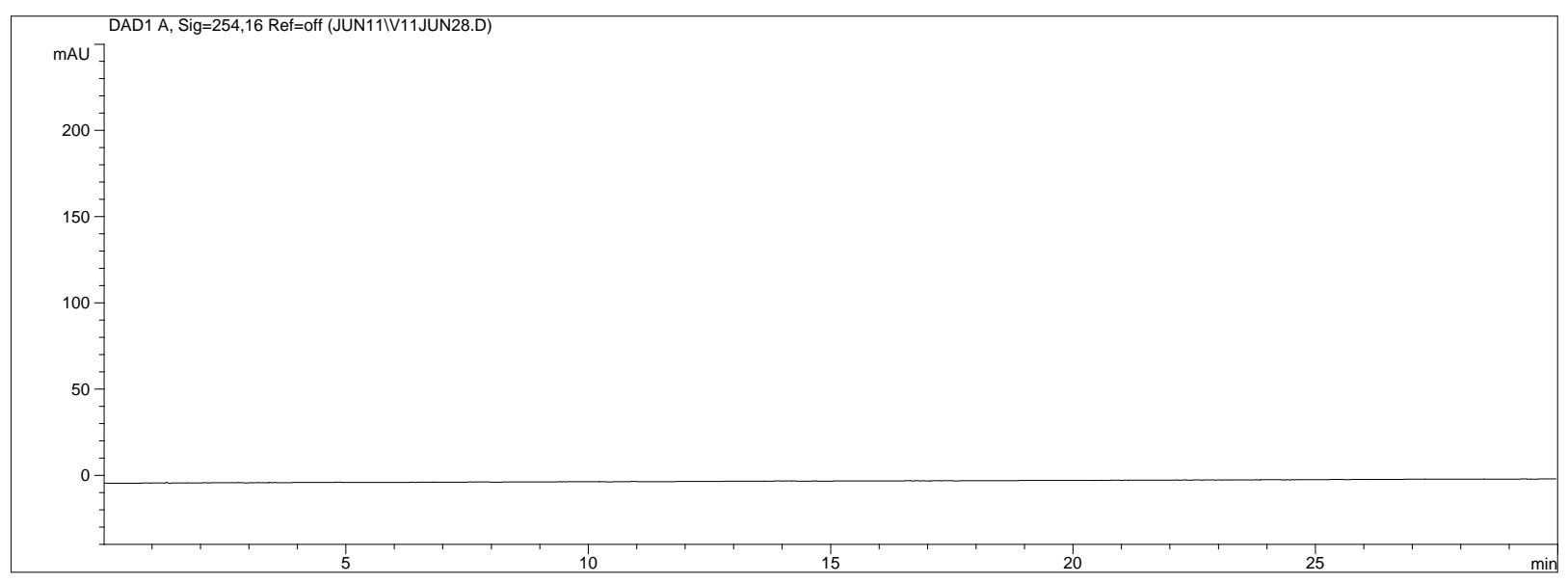

Fig. 2b. Chromatogram of blank solution.

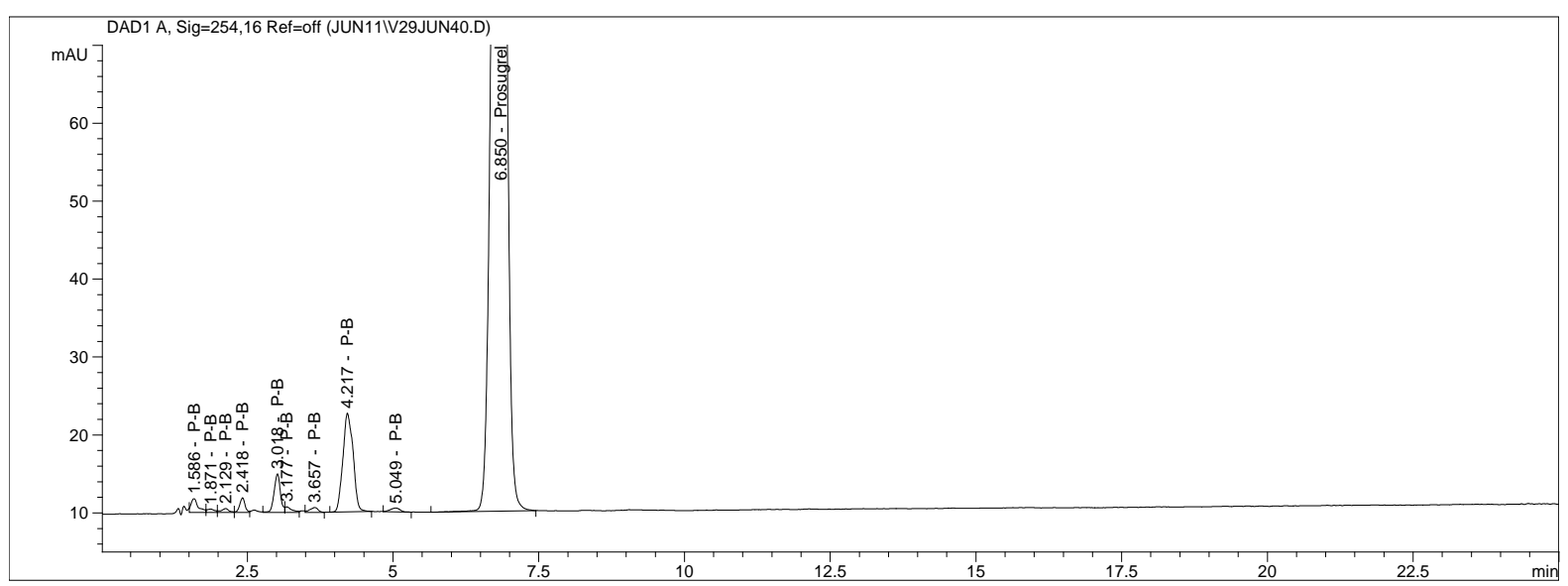

Fig. 2c. Chromatogram of prasugrel alkali hydrolysis degradation. 


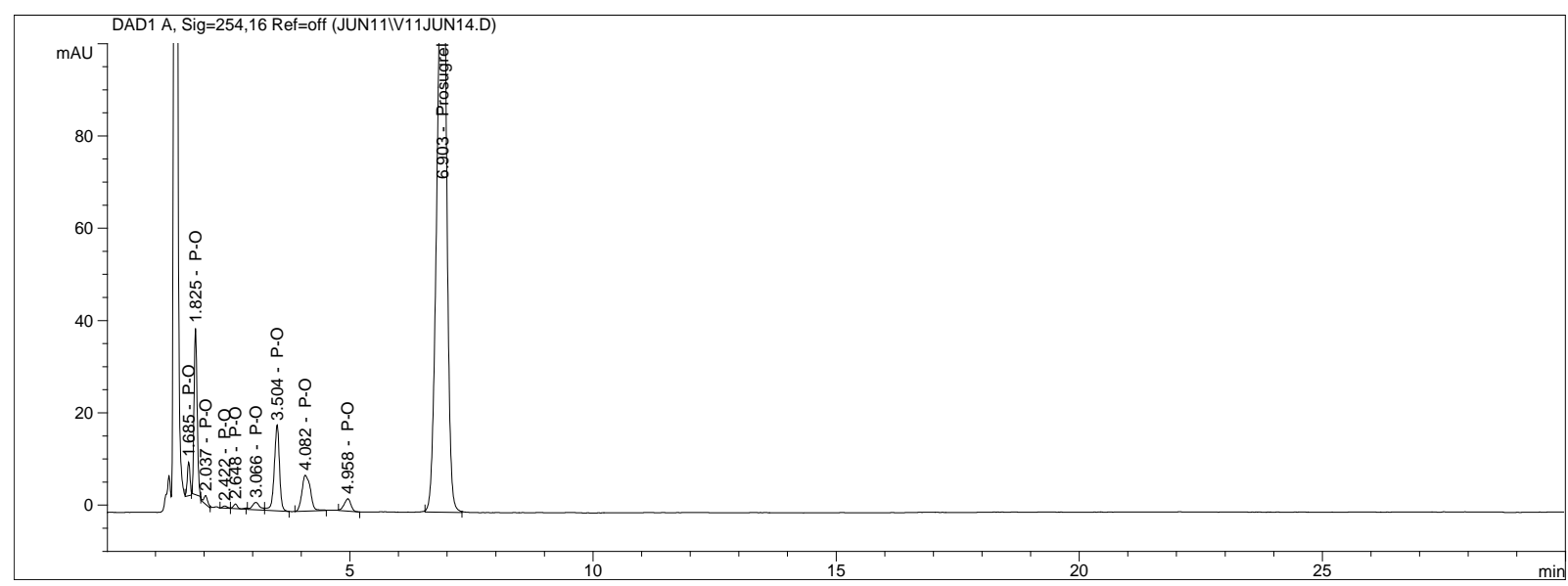

Fig. 2d. Chromatogram of oxidative degradation.

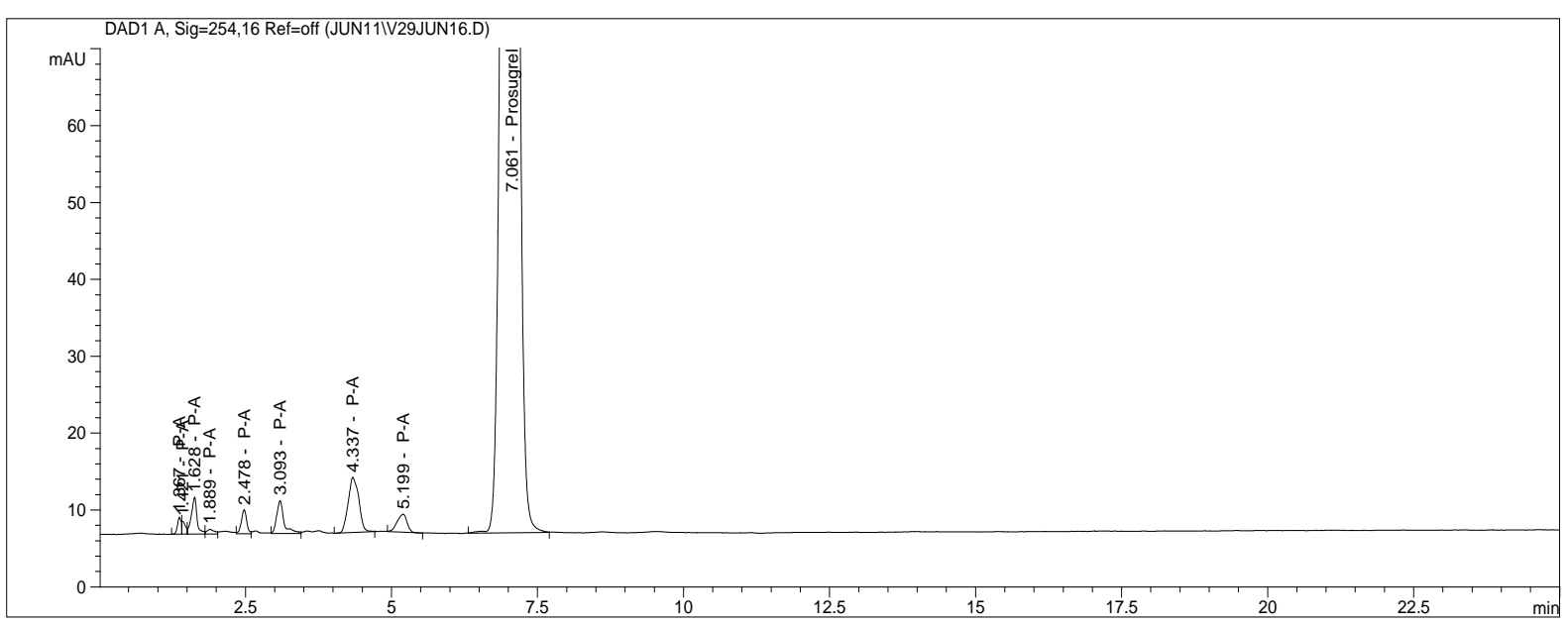

Fig. 2e. Chromatogram of acid hydrolysis degradation.

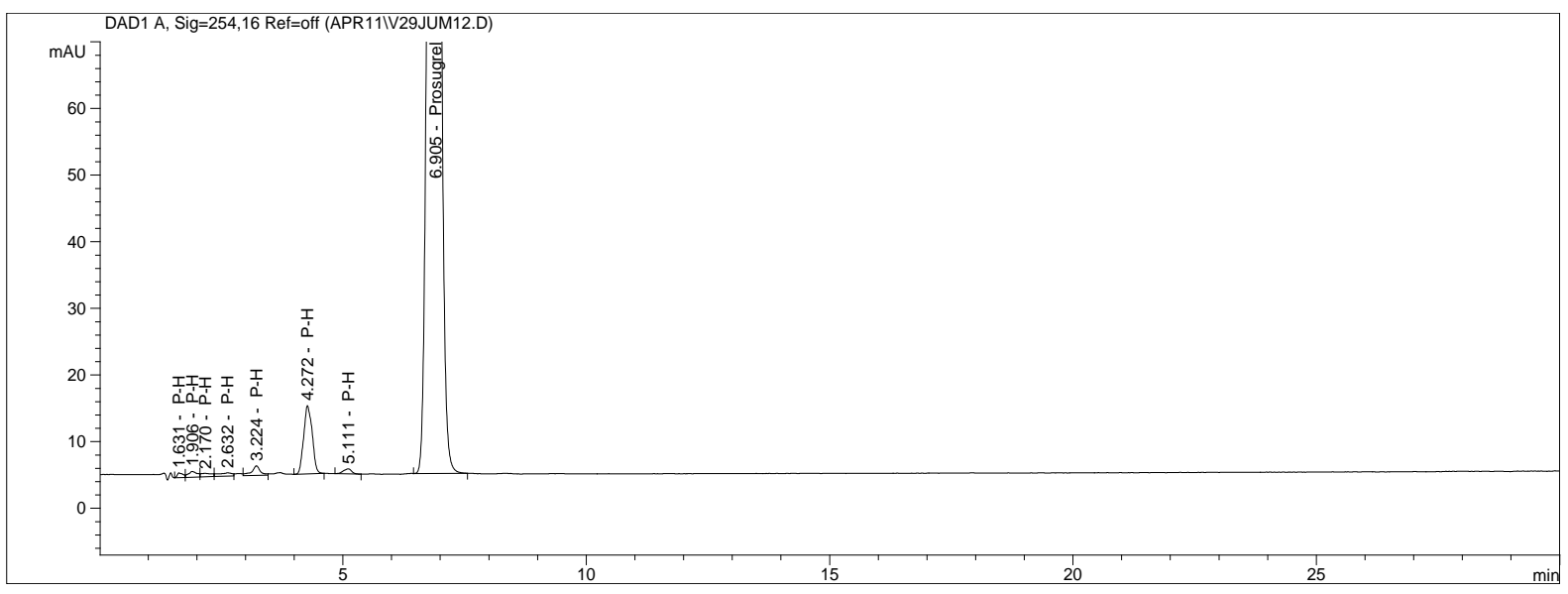

Fig. 2f. Chromatogram of thermal degradation. 

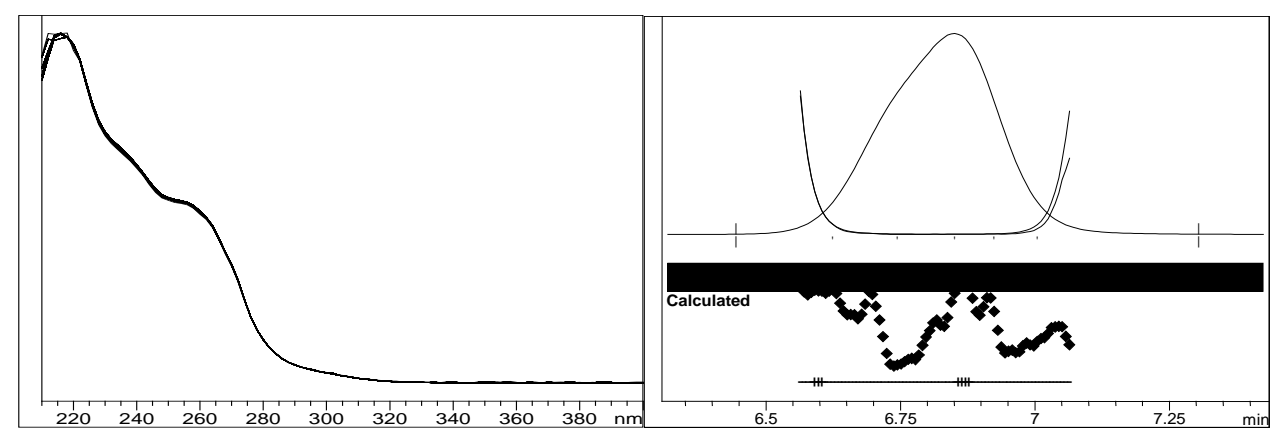

Fig. 3a. Peak purity spectra of prasugrel in alkali hydrolysis degradation

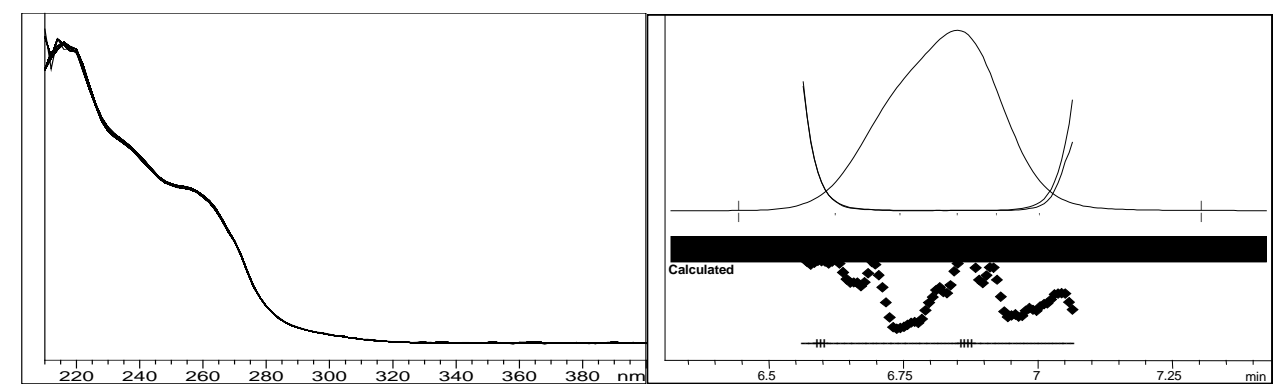

Fig. 3b. Peak purity spectra of prasugrel in oxidative degradation
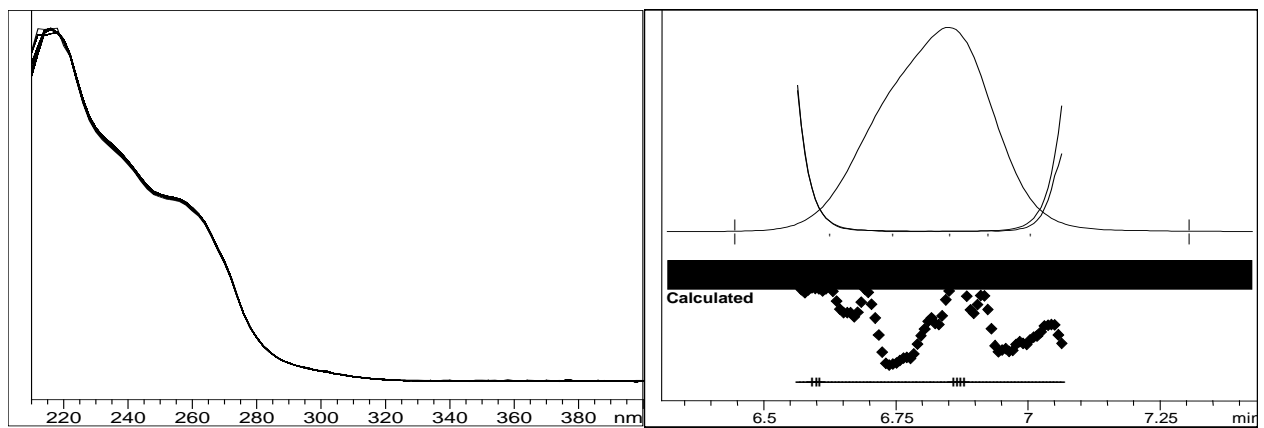

Fig. 3c. Peak purity spectra of prasugrel in acid hydrolysis degradation
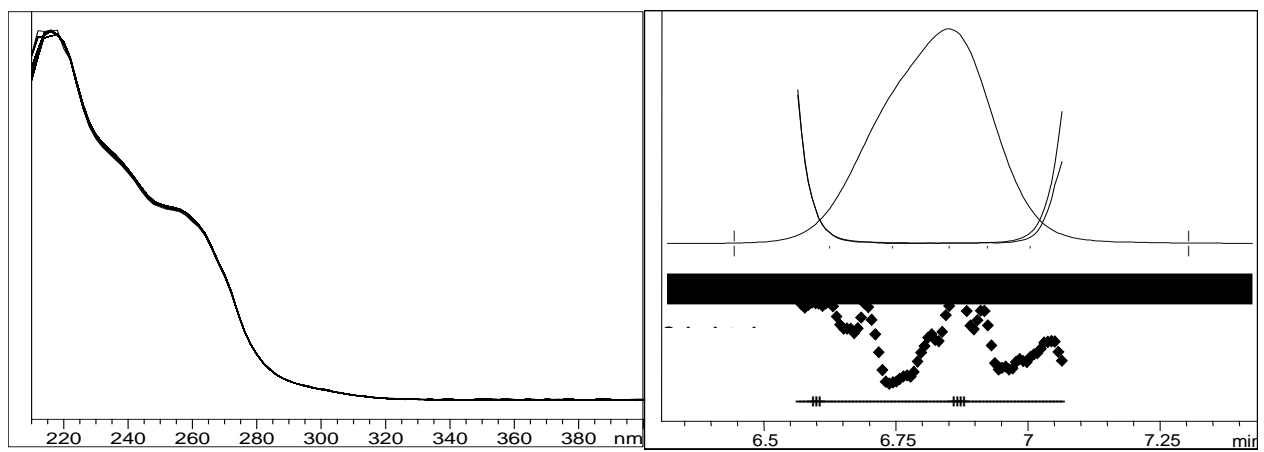

Fig. 3d. Peak purity spectra of prasugrel in thermal degradation 


\section{Acidic degradation}

Weighed and transferred powder equivalent to $20 \mathrm{mg}$ of prasugrel to $10 \mathrm{ml}$ volumetric flask. Add $3 \mathrm{ml} 1 \mathrm{~N} \mathrm{HCl}$ and keep the mixture at $60^{\circ} \mathrm{C}$ for $3 \mathrm{~h}$ in water bath. Allow the solution to attend ambient temperature, then neutralized the solution with $1 \mathrm{~N} \mathrm{NaOH}$ to $\mathrm{pH}$ 7 and the volume is make up with diluent. Further dilute this solution to achieve the concentration $200 \mu \mathrm{g} / \mathrm{ml}$ prasugrel.

\section{Alkali degradation}

Weighed and transferred powder equivalent to $20 \mathrm{mg}$ of prasugrel to $10 \mathrm{ml}$ volumetric flask. Added $3 \mathrm{ml}$ diluent and $2 \mathrm{ml} 0.01 \mathrm{~N} \mathrm{NaOH}$ and kept the mixture at room temperature for $30 \mathrm{~min}$. Neutralized the solution with $0.01 \mathrm{~N} \mathrm{HCl}$ to $\mathrm{pH} 7$ and the volume was made up with diluent. This solution was diluted to achieve the concentration $200 \mu \mathrm{g} / \mathrm{ml}$ of prasugrel.

\section{Oxidative degradation}

Weighed and transferred powder equivalent to $20 \mathrm{mg}$ of prasugrel to $10 \mathrm{ml}$ volumetric flask. Added $3 \mathrm{ml}$ diluent and $2 \mathrm{ml} \mathrm{30 \%}$ hydrogen peroxide and kept the mixture at $60^{\circ} \mathrm{C}$ for $1 \mathrm{~h}$ in water bath. Allowed the solution to attend ambient temperature and the volume was made up with diluent. This solution was diluted to achieve the concentration $200 \mu \mathrm{g} / \mathrm{ml}$ of prasugrel.

\section{Thermal degradation}

Weighed powder equivalent to $20 \mathrm{mg}$ of prasugrel and kept in Petri dish at $90^{\circ} \mathrm{C}$ for $24 \mathrm{~h}$. The solution was prepared to achieve $200 \mu \mathrm{g} / \mathrm{ml}$ of prasugrel.

\section{UV-Short (254 nm) degradation}

About $200 \mathrm{mg}$ of drug product powder were exposed to UV short light for $24 \mathrm{~h}$. The solution was prepared in diluent to achieve $200 \mu \mathrm{g} / \mathrm{ml}$ of prasugrel.

\section{UV-Long (366 $\mathrm{nm}$ ) degradation}

About $200 \mathrm{mg}$ of drug product powder were exposed to UV long light for $24 \mathrm{~h}$. The solution was prepared in diluent to achieve $200 \mu \mathrm{g} / \mathrm{ml}$ of prasugrel.

\section{Results and Discussion}

\section{Optimization of the chromatographic conditions}

To develop a stability-indicating method, it is necessary to separate the analyte peak from degradants peaks. To achieve this, different column stationary phases like C18, CN, C8 tried with different mobile phases containing buffers like phosphate, ammonium acetate and trifluoroacetic acid with different $\mathrm{pH}(3-9)$ and organic modifier (acetonitrile) were used.

Our objective of chromatographic method development was to achieve peak tailing factor $<2$, retention time in between 3 to $10 \mathrm{~min}$. The chromatographic separation of prasugrel from its degradants was achieved using Zorbax XDB $C_{8},(150 \times 4.6 \mathrm{~mm}, 3.5 \mu \mathrm{m}$.) column. In all aforementioned trials, Zorbax $\mathrm{XDB} \mathrm{C}_{8}$ column shows better performance as compared to other $\mathrm{C} 18$ or $\mathrm{CN}$ columns. It was determined that aqueous solution of $0.05 \mathrm{M}$ 
ammonium acetate $\mathrm{pH} 4.5$ with acetic acid and acetonitrile in the ratio of 40:60 $(\mathrm{v} / \mathrm{v})$, the flow rate of mobile phase at $1.0 \mathrm{ml} / \mathrm{min}$ and column temperature at $30^{\circ} \mathrm{C}$ is the optimal condition. It was observed that $\mathrm{pH} 4.5$ of buffer solution helps to reduce the tailing of analyte peak and to increase the efficiency in terms of theoretical plates. The analyte peak shape with less tailing resolved from degradants and the chromatographic analysis time was found to be less than $10 \mathrm{~min}$. In optimized conditions its degradants were well separated. Typical retention time of prasugrel peak is about $7 \mathrm{~min}$. Method development results are shown in Table 1.

Tab. 1. Results of method development.

\begin{tabular}{|c|c|c|c|}
\hline Column & $\begin{array}{c}\text { Retention time } \\
\text { (min) }\end{array}$ & $\begin{array}{c}\text { Theoretical } \\
\text { Plates }\end{array}$ & $\begin{array}{l}\text { USP } \\
\text { Tailing }\end{array}$ \\
\hline $\begin{array}{l}\text { YMC ODS A C18; } \\
25 \mathrm{~cm} \times 4.6 \mathrm{~mm} d ., 5 \mu\end{array}$ & 13.2 & 4723 & 1.6 \\
\hline $\begin{array}{l}\text { Altims CN; } \\
25 \mathrm{~cm} \times 4.6 \mathrm{~mm} \mathrm{d.,5 \mu}\end{array}$ & 5.2 & 3523 & 1.3 \\
\hline $\begin{array}{l}\text { Zorbax XDB C8; } \\
15 \mathrm{~cm} \times 4.6 \mathrm{~mm} \mathrm{d.,3.5 \mu}\end{array}$ & 6.0 & 7023 & 1.1 \\
\hline
\end{tabular}

\section{Results of forced degradation study}

Though conditions used for forced degradation were attenuated to achieve degradation in the range of $10-30 \%$, this could not be achieved in case of photolytic degradation even after exposure for prolonged duration [18]. During the initial forced degradation experiments, it was observed that alkali hydrolysis was a fast reaction for almost complete degradation occurred when $0.5 \mathrm{~N} \mathrm{NaOH}$ solution is used. The drug product showed extensive degradation in acid hydrolysis, alkali hydrolysis and oxidative and thermal condition. The hydrolytic degradation observed in both alkali and acidic condition may be due to the presence of carboxyl group into the structure, which results in formation of polar degradants (acid). Also in acidic conditions nitrogen containing ring may undergo protonation and by cleavage it will form polar impurities. Hence, we observed the polar impurities in acid and alkali degradation. Similar type of degradation was reported in clopidogrel which belongs to same class thienopyridine $[19,20]$. Also in oxidative condition, reactive sites present in compound oxidized and formed different degradation products. In thermal condition, at moderate temperature no degradation was observed; but, as we employed harsh conditions over a long period, it leads to degradation of prasugrel. Table 2 indicates the extent of degradation, peak purity and assay of prasugrel under various stress conditions. Chromatographic peak purity data was obtained from the spectral analysis report. The peak purity value was found to be greater than 990 , indicating a homogeneous peak and thus establishing the specificity of assay method. Fig. $2 a$ to $2 f$ shows the chromatograms of tablet solution, diluent, alkali hydrolysis degradation, oxidative degradation, acid hydrolysis degradation and thermal degradation, respectively. Fig. 3a to $3 d$ shows peak purity spectra of prasugrel in presence of it degradants. Assay of prasugrel was unaffected by the presence of other degradants which confirms the stabilityindicating power of the method. 
Tab. 2. Results of analysis of forced degradation study

\begin{tabular}{lccc}
\hline Stress condition & Degradation (\%) & Peak purity $^{\text {a }}$ & Assay (\%) $^{\circ}$ \\
\hline Acidic $\left(60^{\circ} \mathrm{C} / 3 \mathrm{hr}\right)$ & 11.33 & 999.915 & 88.38 \\
Alkali $(\mathrm{RT} / 30 \mathrm{~min})$ & 13.38 & 999.743 & 86.26 \\
Oxidative $\left(60^{\circ} \mathrm{C} / 1 \mathrm{hr}\right)$ & 19.18 & 999.592 & 81.23 \\
Thermal $\left(90^{\circ} \mathrm{C} / 24 \mathrm{hr}\right)$ & 6.11 & 999.831 & 93.13 \\
UV-short $(24 \mathrm{hr})$ & No degradation & 999.901 & 99.33 \\
UV-long $(24 \mathrm{hr})$ & No degradation & 999.925 & 99.69 \\
\hline${ }^{a}$ peak purity values in the range of $990-1000$ indicate a homogeneous peak.
\end{tabular}

\section{Method validation}

\section{Specificity}

Specificity is the ability to measure accurately and specifically the analyte of interest in the presence of other components that may be expected to be present in the sample matrix. It was found that the proposed method was specific because there is no interference of diluent and excipients ensuring that the peak response is due to only a single component. Photodiode array detection was used as an evidence of the specificity of the method and to evaluate the homogeneity of the analyte peak. The peak purity values that are more than 999 for drug product show that the peaks of analyte were pure. Formulation excipients and degradants were also not interfering with the analyte peak.

\section{Calibration and linearity:}

Linearity experiment was tested from range of 10 to $200 \%$ of the targeted level assay concentration $200 \mu \mathrm{g} / \mathrm{ml}$. The linearity solutions were injected in triplicate. The calibration graph was obtained by plotting peak area against the concentration of the drug. The equation of the calibration curve $y=9.327 x+0.7701$. The calibration graph was found to be linear in the aforementioned concentrations with correlation coefficient 0.999 .

\section{Precision (repeatability):}

The precision of the proposed method was evaluated by carrying out six independent $(200 \mu \mathrm{g} / \mathrm{ml})$ assays of test sample. RSD (\%) of six assay values was calculated. Intermediate precision was carried out by analyzing the samples by different analyst on another instrument. Table 3 indicates the results of the precision study, which shows the method is reliable $(\mathrm{RSD} \%<2)$.

Tab. 3. Precision data

\begin{tabular}{lcc}
\hline Analyst & $\begin{array}{c}\text { Assay (\%) } \\
(\mathbf{n = 6})\end{array}$ & \% RSD \\
\hline Analyst-1 & 99.23 & 0.59 \\
Analyst-2 & 99.63 & 0.86 \\
\hline
\end{tabular}




\section{Accuracy (recovery test)}

Accuracy of the method was studied by recovery experiments. The recovery experiments were performed by adding known amounts of drug in the placebo. The recovery was performed at three levels: $80 \%, 100 \%$ and $120 \%$ of the label claim of the tablet (10 mg of prasugrel). The recovery samples were prepared as per the procedure mentioned in preparation of sample. Three samples were prepared for each recovery level. The solutions were then analyzed, and the percentage recoveries were calculated. The recovery value for prasugrel ranged from 98.88 to $100.59 \%$. The average recovery of three levels (nine determinations) was 99.76\%. Results are shown in Table 4.

Tab. 4. Results of Accuracy experiment using proposed method.

\begin{tabular}{lccc}
\hline Level (\%) & $\begin{array}{c}\text { Amount of drug } \\
\text { spiked (mg) }\end{array}$ & \begin{tabular}{c} 
Found \\
\cline { 2 - 4 }
\end{tabular} & $\begin{array}{c}\text { Recovery\% } \\
(\mathbf{m g})\end{array}$ \\
\hline 80 & 8.13 & 8.09 & 99.39 \\
100 & 10.19 & 10.2 & 100.12 \\
120 & 12.35 & 12.33 & 99.78 \\
\hline
\end{tabular}

\section{Robustness}

The robustness is the ability of method to remain unaffected by small changes in parameters. To determine robustness of the method, experimental conditions were purposely altered and assay, peak tailing, theoretical plates and peak area \%RSD were evaluated. The flow rate of the mobile phase was $1.0 \mathrm{ml} / \mathrm{min}$. To study the effect of flow rate it was changed to 0.1 units from 1.0 to $0.9 \mathrm{ml} / \mathrm{min}$ and $1.1 \mathrm{ml} / \mathrm{min}$. The effect of column temperature was studied at $28^{\circ} \mathrm{C}$ and $32^{\circ} \mathrm{C}$ instead of $30^{\circ} \mathrm{C}$, while other mobile phase components were kept constant. The effect of mobile phase composition was studied in aqueous solution of $0.05 \mathrm{M}$ ammonium acetate $\mathrm{pH} 4.5$ with acetic acid: acetonitrile $(38: 62 \mathrm{v} / \mathrm{v})$ and $(42: 58 \mathrm{v} / \mathrm{v})$. At all conditions sample was assayed in triplicate. The effect of detection wavelength was studied at $250 \mathrm{~nm}$ and $258 \mathrm{~nm}$. Assay $\%$ at all deliberate conditions within 98.81 to $99.88 \%$. Results are shown in table 5 .

Tab. 5. Results of robustness study.

\begin{tabular}{lllc}
\hline Sr. no. & Parameter & Variation & $\begin{array}{c}\text { Assay } \% \\
(\mathbf{n}=3)\end{array}$ \\
\hline \multirow{2}{*}{ 1. } & Flow rate $( \pm 10 \%$ of the set flow) & a) At $0.9 \mathrm{ml} / \mathrm{min}$ & 99.56 \\
& b) At $1.1 \mathrm{ml} / \mathrm{min}$ & 99.18 \\
\hline \multirow{2}{*}{ 2. } & Mobile phase composition & a) At $62 \mathrm{ml}$ & 98.97 \\
\hline \multirow{2}{*}{3.} & $( \pm 2 \%$ of organic modifier $)$ & b) At $58 \mathrm{ml}$ & 99.32 \\
\hline \multirow{2}{*}{4.} & Temperature & a) At $28^{\circ} \mathrm{C}$ & 98.81 \\
& $\left( \pm 2^{\circ} \mathrm{C}\right.$ of set temperature $)$ & b) At $32^{\circ} \mathrm{C}$ & 99.23 \\
\hline
\end{tabular}




\section{Determination of limit of quantification and limit of detection (LOQ \& LOD)}

The detection and quantification limits were evaluated from calibration curves plotted in concentration range of detection level $-300 \mu \mathrm{g} / \mathrm{ml}$. The formula used were LOD $=3.3 \sigma / \mathrm{S}$ and $L O Q=10 \sigma / S$ (where $\sigma=$ standard deviation of response and $S=$ slope of calibration curve). LOD and LOQ for this method were found to be 0.110 and 0.364 , respectively. These values indicated the method was very sensitive to quantify the drug.

The standard drug solutions for each value of LOD and LOQ concentration were injected 6 times. \% RSD values for the area of replicate injections were calculated.

\section{Solution stability}

The stability of standard solution was tested at the intervals of 12 and $24 \mathrm{~h}$. The stability of solutions was determined by comparing results of area $\%$ and peak purity of prasugrel. The area $\%$ values were found to be within $0.5 \%$ after $24 \mathrm{~h}$. The results indicate that the solution was stable for $24 \mathrm{~h}$ at ambient temperature as there was no formation of any unknown peak and solution remains stable. The RSD of peak area\% and peak purity were $0.32 \%, 999.983$, respectively.

\section{Conclusion}

The LC method described here is a very simple, sensitive and accurate procedure for the estimation of prasugrel. The developed and validated LC method is stability-indicating and enables specific, accurate, robust and precise analysis of prasugrel in formulation. The method is sensitive enough for quantitative detection of the analyte in pharmaceutical preparations. Thus the proposed method can be used for routine analysis in quality control departments and for studies of the stability of pharmaceutical tablets. The validation data indicate good precision, accuracy and reliability of the method. The sample recoveries in formulations were in agreement with their respective label claim and suggested noninterference of formulation excipients in the estimation of prasugrel.

\section{Acknowledgments}

The authors are grateful to the Lupin pharmaceutical Ltd (Mumbai, India) for gift sample of prasugrel and Head-Department of chemistry, Deogiri College of Science Aurangabad, India for providing laboratory facility for this research work.

\section{Authors' Statement}

\section{Competing Interests}

The authors declare no conflict of interest.

\section{References}

[1] Baker WL, White CM.

Role of Prasugrel, a Novel P2Y12Receptor Antagonist, in the Management of Acute Coronary Syndromes.

Am J Cardiovasc Drugs. 2009; 9: 213-229.

http://dx.doi.org/10.2165/1131209 
[2] Mousa SA, Jeske WP, Fareed J.

Prasugrel: a novel platelet ADP P2Y(12) receptor antagonist.

Methods Mol Biol. 2010; 663: 221-228.

http://dx.doi.org/10.1007/978-1-60761-803-4_8

[3] Serebruany V, Makarov L.

Prasugrel for arterial coronary thrombosis.

Drugs Today. 2009; 45: 83-91.

http://www.ncbi.nlm.nih.gov/pubmed/19343228

[4] Wiviott SD, Braunwald E, McCabe CH, Montalescot G, Ruzyllo W, Gottlieb S, Neumann FJ, Ardissino D, De Servi S, Murphy SA, Riesmeyer J, Weerakkody G, Gibson CM, Antman EM; TRITON-TIMI 38 Investigators.

Prasugrel versus clopidogrel in patients with acute coronary syndromes.

N Engl J Med. 357; 2007: 2001-2015.

http://dx.doi.org/10.1056/NEJMoa0706482

[5] Braun OO, Johnell M, Varenhorst C, James S, Brandt JT, Jakubowski JA, Winters KJ, Wallentin L, Erlinge D, Siegbahn A.

Greater reduction of platelet activation markers and platelet-monocyte aggregates by prasugrel compared to clopidogrel in stable coronary artery disease.

Thromb Haemost. 2008; 100: 626-663.

http://dx.doi.org/10.1160/TH08-05-0313

[6] Michelson AD, Frelinger AL, Braunwald E, Downey WE, Angiolillo DJ, Xenopoulos NP, Jakubowski JA, Li Y, Murphy SA, Qin J, McCabe CH, Antman EM, Wiviott SD.

TRITON-TIMI 38 Investigators Pharmacodynamic assessment of platelet inhibition by prasugrel vs. clopidogrel in the TRITON-TIMI 38 trial.

Eur Heart J. 2009; 30: 1753-1763.

http://dx.doi.org/10.1093/eurheartj/ehp159

[7] Jakubowski JA, Matsushima N, Asai F, Naganuma H, Brandt JT, Hirota T, Freestone S, Winters KJ. A multiple dose study of prasugrel (CS-747), a novel thienopyridine P2Y12 inhibitor, compared with clopidogrel in healthy humans.

Br J Clin Pharmacol. 2007; 63: 421-430.

http://dx.doi.org/10.1111/j.1365-2125.2006.02792.x

[8] Chang WC, Midodzi WK, Westerhout CM, Boersma E, Cooper J, Barnathan ES, Simoons ML, Wallentin L, Ohman EM, Armstrong PW.

Are international differences in the outcomes of acute coronary syndromes apparent or real? A multilevel analysis.

J Epidemiol Community Health. 2005; 59: 427-433.

http://dx.doi.org/10.1136/jech.2004.024984

[9] International Conference on Harmonisation (ICH).

Topic Q1A (R2). Stability testing of new drug substances and products.

Geneva, Switzerland 2003

[10] Wickremsinhe ER, Tian Ye, Ruterbories KJ, VerburgEM, Weerakkody GJ, Kurihara A, Farid NA. Stereoselective Metabolism of Prasugrel in Humans Using a Novel Chiral Liquid ChromatographyTandem Mass Spectrometry Method.

Drug Metab Dispos. 2007; 35: 917-921.

http://dx.doi.org/10.1124/dmd.106.014530

[11] Lukram O, Zarapkar M, Jha CK, Parmar S, Tomar KS, Hande A.

Electrospray ionization LC-MS/MS validated method for the determination of the active metabolite (R-138727) of prasugrel in human plasma and its application to a bioequivalence study.

Drug Test Anal. 2012; 4: 158-166.

http://dx.doi.org/10.1002/dta.2641 
[12] Farid NA, McIntosh M, Garofolo F, Wong E, Shwajch A, Kennedy M, Young M, Sarkar P. Kawabata K, Takahash M, Pang $\mathrm{H}$.

Determination of the active and inactive metabolites of prasugrel in human plasma by liquid chromatography/tandem mass spectrometry.

Rapid Commun Mass Spectrom. 2007; 21: 169-179.

http://dx.doi.org/10.1002/rcm.2813

[13] Borole TC, Mehendre R, Damle MC, Bothara KG.

Development and validation of stability indicating HPTLC method for determination of Prasugrel.

J Chem Pharm Res. 2010; 2: 907-913.

[14] Prabahar AE, Rao NR, Sambasiva Rao KRS, Vijayaraj Kumar P.

Method development and validation for the HPLC potency assay of prasugrel tablets.

J Pharm Res. 2011; 4: 980-982.

[15] Ashok Kumar A, Laxmiram M, Bharat Kumar B, Swamy G, Das R, Sankar DG.

Spectrometric determination of prasugrel in bulk drug and in its pharmaceutical formulation by UV method.

Pharmanest. 2011; 2: 55-57.

[16] Jena FM, Ravi Kumar BVV, Viriyala RK Annapurna MM, Bisht SP.

Validated new spectrophotometric methods for the estimation of prasugrel in bulk drug and pharmaceutical dosage forms.

Int J Compr Pharm, 2011; 2: 1-3.

[17] Bakshi M, Singh S.

Development of validated stability-indicating assay methods critical review.

J Pharm Biomed Anal. 2002; 28: 1011-1040.

http://dx.doi.org/10.1016/S0731-7085(02)00047-X

[18] International Conference on Harmonisation (ICH).

Topic Q2 (R1). Validation of analytical procedures: Text and Methodology.

Geneva, Switzerland November 2005.

[19] Antić D, Filipić S, Agbaba D.

A simple and sensitive TLC method for determination of clopidogrel and its impurity SR 26334 in pharmaceutical products.

Acta Chromatogr. 2007; 18: 199-206.

[20] Raijada DK, Prasad B, Paudel A, Shah RP, Singh S.

Characterization of degradation products of amorphous and polymorphic forms of clopidogrel bisulphate under solid state stress conditions.

J Pharm Biomed Anal. 2010; 52: 332-344.

http://dx.doi.org/10.1016/j.jpba.2009.05.001 